\title{
Reattaching Shadows: Dancing with Schopenhauer
}

\author{
Joshua Maloy Hall
}

$\ldots$ and she got out her needle, and sewed the shadow on Peter's foot ... and [he] continued to dance.

(J. M. Barrie, Peter Pan)

In this essay, I will explore the relationship between Schopenhauer and dance. The most important aspects of this relationship unfold in The World as Will and Representation (hereafter WWR), but there are a few brief mentions of dance outside of Schopenhauer's magnum opus, most of which are similarly pejorative. For example, in "On Women" he contrasts the "frivolous" ways in which a little girl typically interacts with an infant, including dancing with the infant, with all the good a man could do if he were the one interacting with the infant (63). ${ }^{1}$ As for the secondary literature on Schopenhauer, it unfortunately ignores dance almost completely. ${ }^{2}$ Although the present essay therefore represents a significant departure vis-à-vis Schopenhauer's philosophy and scholarship, it is nevertheless consistent with other, broader trends in humanities scholarship, including an increasing focus on dance in philosophical aesthetics, Judith Butler-inspired work in feminist and cultural theory on embodiment as performance, and the inclusion of explicitly philosophical perspectives in the developing interdisciplinary field of dance studies. ${ }^{3}$ 
In brief, I will argue here that contemporary philosopher of dance Francis Sparshott is mistaken when he writes that Schopenhauer would have embraced dance had it been a more respectable, independent art form in his era, since Schopenhauer's resistance to it is based, more importantly, on dance's tendency to life-affirmation. Instead, put in terms of my titular shadow metaphor, dance's optimism and joy are the wrongly-excised shadow that, when reattached to Schopenhauer's philosophy, provides a new opportunity for that philosophy to overcome its own pessimism.

The structure of my investigation is as follows. I will begin with Schopenhauer's very brief explicit mention of dance, and then try to understand the exclusion of dance from his extended discussion of the individual arts. Toward this latter end I will then turn to Francis Sparshott essay, which situates Schopenhauer's thought in terms of Plato's privileging of dance (in the Laws) as the consummate participatory art, and which observes that Schopenhauer's dance is that of Shiva, lord of death. In light of these two moments, I will then offer a brief examination of the Laws' account of dance, and two essays by Avanthi Meduri's on classical Indian dance. Next, to help explain Schopenhauer's negative position vis-à-vis Plato and Vedantic thought, I will invoke Schopenhauer's own conception of madness qua disconnection. Finally, I will attempt to cure this "madness" in Schopenhauer-as Wendy did for Peter Pan when he lost his shadow and could not reattach it himself-by sewing together Schopenhauer's conceptions of embodiment and music, and in effect reattaching the shadow to the body of Schopenhauer's position on dance using the thread of his own philosophy. In short, I will show how even a thought as life-denying as Schopenhauer's can—with the help of dance-overcome itself into life-affirmation. 
Before getting into the heart of this analysis, however, it might help to clarify what I mean in this essay by "dance." Although there is an ongoing discussion of this topic in the secondary literature ${ }^{4}$ for my purposes here I am content with a fairly straightforward extensional definition. "Dance," in this essay, should be understood to refer to ballet, modern, postmodern, jazz, tap, lyrical, clogging, and other folk, ballroom, club, and religious dance (although this list is not intended to be exhaustive). By contrast, an intensional definition of dance would attempt to describe the essential qualities that something would have to possess in order to count as dance. One might, for example, define dance as the art of movement for its own sake. This definition, however, would be unacceptable to many contemporary thinkers, because it would exclude many forms of dance, such as ritual dance (due to the latter's having an instrumental purpose).

The most important implication of the above extensional definition for the present essay is that any type of dance (though I focus here on classical Indian dance) could be equally relevant vis-à-vis Schopenhauer's philosophy. Put simply, I choose classical Indian dance primarily because it is a dance tradition to which Schopenhauer specifically refers, and it is connected to the Advaita Vedantic tradition (often referred to as "Vedic" or "Hindu"), which is famously central to Schopenhauer's philosophy as a whole. In other words, although classical Indian dance seems to me the best way to make my case, all dance here is on the table.

\section{The Body of the Position}

Schopenhauer only mentions dance explicitly four times in his magnum opus, and every time the connotation is negative. The first instance comes from WWR Vol. I, Sec. 52, on music: "The short, intelligible phrases of rapid dance music seem to speak only of ordinary happiness which is easy of attainment" (261). To a contemporary Western ear, there is nothing obviously 
lacking in either ordinary happiness or easy attainment, but Schopenhauer's problem is that happiness passes away just as easily as it arrives - and in fact reduces to the mere lack of suffering, as a kind of metaphysical absence. Complementing this idea, he observes that "dance music in the minor key seems to express the failure of the trifling happiness that we ought rather to disdain" (261). Given that a majority of dance music is set in the major key, however, it seems like dancing belongs more with the delusional affirmation of the will than with an acknowledgment of its futility. Note, though, that dance is not considered "in itself," whatever that might mean, but only in relation to the music to which it is danced. A further difficulty with this picture is that dance, while it lasts, seems to sustain perfectly the cycle of desires and satisfactions, due to its allegro speed, with absolutely no time between the desire to move and the execution of the movement. My point here is that, although such happiness is short from a longterm perspective, it is nevertheless omnipresent within the temporality of the dance.

Dance reappears in the addendum on music in WWR, Vol. II, Ch. 39, again in its connection to the minor key: "Allegro in the minor key is very frequent in French dance music; it is as if a man danced while his shoe pinched him" (456). Schopenhauer here compares the existential pain of the frustration of the will that occurs in minor music with the physical pain of dancing in uncomfortable shoes. One might wonder why Schopenhauer is suggesting that dance cannot harness sadness in a natural and apt way, but only through an inappropriate and unnatural deformation of its procedure. In other words, only by dancing the wrong way, with an external impediment like a too-small shoe, is the minor key expressed. Why does Schopenhauer not allow the possibility that dance is naturally equipped to linger with the sadness and anguish depicted in minor key music, perhaps even as naturally as it expresses happiness or satisfaction in the major key? One could even suggest that the ability to meaningfully dance to minor key music would be 
indicative of a kind of penchant for renunciation, the chief characteristic of the Schopenhauerian saint.

Much later, toward the beginning of the Fourth Book, Schopenhauer uses the phrase "the dance" as a metaphor for his analysis of the fundamental nature of human reality, in which "every human life is tossed backwards and forwards between pain and boredom" (315). Dance suffers again here from an unremittingly negative association-dance as metaphor for the alternating pain and boredom that characterizes human life. It seems strange that Schopenhauer would use as a metaphor for his fundamental view of human nature an art form that receives no direct treatment and almost no indirect treatment in his work. Clearly, the analogy with dance is not perfect with regard to the commonsensical understanding of dancing. That is, the dancer, "tossed backwards and forwards," has no perceptible agency in Schopenhauer's description, but rather seems to be moved by an external power, like a puppet. The "dance" he evokes, in other words, is one in which the will is dancing us, or dancing through us.

The fourth and final reference to dance occurs toward the end of the book, in Schopenhauer's extended discussion of saintly renunciation, in a passage explaining how several world religions converge with his philosophy in seeking salvation through world-denial. At the end of a nearly page-long sentence, full of examples of Vedanta's denial of self-love, Schopenhauer mentions that Vedantic saints occasionally go "so far as voluntary death by ... flinging [themselves] under the wheels of the huge car that drives round with the images of the gods amid the singing, shouting, and dancing of the bayaderes" (WWR 388). "Bayaderes" is a Portuguese approximation of the French word for "dancers," a Western appellation for the devadasis, Vedantic temple dancers. As the reader will observe below, many Vedantic philosophers, especially those of Schopenhauer's era, considered the dance of the devadasis, 
called bharata natyam, to be as spiritually elevated as any practice in Vedantic thought, and part of one of the many routes to spiritual liberation and salvation through renunciation of the will.

These four occurrences exhaust the use of the word "dance" in Schopenhauer's The World as Will and Representation, and thus what I am calling the "body" of his position on dance. This body is admittedly a frail and undernourished one, but as with any object in the twilight of sunrise and sunset, powerful external illuminations create much longer shadows, to which I now turn.

\section{The Shadow of the Position}

Physics tells us that the shadow is essentially an absence, a place from which something is missing due to a body's blocking the light. The most noticeable place from which dance is absent in Schopenhauer is his list of the arts. From WWR Vol. I, Sec. 43 to 51, Schopenhauer discusses the individual arts in considerable detail, beginning with architecture and hydraulics ("the artistic arrangement of water"). He then moves to horticulture, landscape painting, animal painting, and sculpture, then historical painting, portraits, and sculptures of humans, and then concludes the regular list with various kinds of poetry. Finally, he concludes the entire discussion with a privileged account of music. Attempting a more balanced organization, one could say that Schopenhauer's list of the arts is as follows: architecture, sculpture, painting, poetry, and music - the same, perhaps significantly, as that of Hegel.

Though there is room here for hydraulics and horticulture, and despite the content just observed above, there is no room in either Hegel's or Schopenhauer's list for dance. To explore why this is the case, I turn now to Francis Sparshott's essay "On the Question: 'Why Do Philosophers Neglect the Aesthetics of the Dance?"' Sparshott's complete set of arguments is 
beyond the scope of this essay, but I do wish to consider briefly his arguments for its exclusion from, more specifically, the $19^{\text {th }}$ century, Hegel, and Schopenhauer.

Sparshott claims that it is "important that dance has no determinate place in [Hegel's] scheme," not "alongside sculpture at the center" due to its putting the grace of the human body in motion, nor "alongside architecture as the primitive art" due to their shared reliance on brute "materiality." As to why this is the case, Sparshott argues that "in Hegel's day dance had nothing to offer of more significance than ... mere spectacle," and spectacle for Hegel quite simply "is not art" at all (Sparshott 7). In particular, Romantic ballet, the preeminent art dance of the $19^{\text {th }}$ century, Sparshott terms "posthumous," with a "mood" of "impotent nostalgia" due to its arriving on the scene in the same year as "the end of the creative epoch of romanticism in literature and the arts" (9). Hegel, as opposed to Schopenhauer, does at least mention dance in his discussion of the individual arts, denoting it "an imperfect art" whose only claim to importance is that it "alludes to the movements of the heavenly bodies," but this only in a "merely universal and abstract" way. In the last analysis, Sparshott views dance's absence from Hegel's (and others') catalogues of serious art as resulting from its inability to "be related to some specific metaphysical principle or some general concern of mankind" (11).

As has already been observed, however, dance serves as an apt metaphor for Schopenhauer's primary metaphysical principle - the dance back and forth between pain and boredom. Sparshott notes this aptitude of dance for Schopenhauer's metaphysics, and even goes so far as to argue that Schopenhauer puts music in the place rightfully belonging to dance simply because of dance's diminished status during his time (12). Thus, according to Sparshott, had Schopenhauer been privileged to experience a dance art superior to that of Romantic ballet, he would be regarded today as its arch-apologist. More specifically, Sparshott claims that 
Schopenhauer's thought as a whole in The World as Will and Representation "can be construed as the Platonic contrast between the dance which citizens know by participation and the arts that furnish them with objects for contemplation" (12). Sparshott is here referring specifically to Plato's Laws, which “devotes much space to the principles of dance as the symbolic center of civic activity, and carefully distinguishes this sort of dance from dances of professional display" (11). It is this account of participation-dance, choros, in Plato's Laws, that Sparshott claims Schopenhauer replaced with music. Significantly for my analyses below, Sparshott adds in a brief footnote to this passage that the specific dance ousted by music "would be the dance of Shiva, Lord of the Dead: Schopenhauer invokes traditional Indian thought" (54 n.).

While I would dispute the accuracy and subtlety of Sparshott's sweeping generalizations about Plato and Advaita thought, I will nevertheless explore these two attributed ancestriesPlato's Laws and classical Advaita thought—as elongated shadows behind Schopenhauer's own limited references to dance. It will be largely on the basis of the genealogical relationship between these traditions that I will argue ultimately that Schopenhauer's own thoughtspecifically on embodiment and music_possesses the resources on its own to justify the reintegration and valorization of the art of dance into his scheme of aesthetics and philosophy as a whole.

\section{A Precedence of Dancing Laws}

Toward the beginning of Plato's Laws, one of the interlocutors remarks to the aged stranger from Athens that Athenians "alone are good by their own nature without compulsion, by a divine dispensation: they are truly, and not artificially, good" (Plato 642d). This comment comes just before the stranger sets out to define education, which is of course the reason why 
adult Athenians are truly good, because "the good are those able to rule themselves" (644b). As it turns out, this is exactly what is meant by education, which the Stranger claims "makes one desire and love to become a perfect citizen who knows how to rule and be ruled with justice" (643e-644a). The laws of the city are the incorporated virtues of its citizens beginning with childhood, in fact even before birth. Those educated in virtue rule themselves, which means (in the terms of the Phaedrus) that the sensuous and passionate parts of their souls are controlled by the rational parts. Thus, for the Stranger, as for Schopenhauer, virtue lies in self-control, in a kind of resignation of willful desire to the dictates of reality - in Plato's case, the reality of the polis. Therefore, Plato's education should recommend itself to Schopenhauer for his education of the will into the truth of saintly renunciation.

Just below this passage, the Stranger suggests thinking of ourselves as "divine puppets" whose "passions work within us like tendons or cords, drawing us and pulling against one another in opposite directions toward opposing deeds, struggling in the region where virtue and vice lie separated from one another" (644e). The figure of the puppet recurs later in the dialogue, in the context of an imaginary contest to decide whose art can bring the most pleasure to the polis. "It wouldn't be surprising," observes the Stranger, "if someone thought he could best win by presenting puppets," which is what he predicts would happen if the judges for such a contest were "very little children" (658c). The puppet makes a third appearance in the text when the Stranger says that humans are like puppets "for the most part" (804b). He then, however, immediately apologizes for "belittling our human race" under the influence of "the god" (804b), probably referring to Apollo or Dionysus (whom I will consider more extensively below).

Moving beyond the dialogue, the figure of the puppet is often invoked as a metaphor for dance. Dancers are puppets at the mercy of the puppet masters that are their choreographers, 
instructors, librettists, etc. One popular exercise for training dancers in proper posture, in fact, and one which becomes a critical aspect of the Stranger's philosophy of education, is the following: imagine that you are a puppet with a string extending upwards from the center of the top of your head, and that the rest of your body hangs limp beneath the string. In other words, being a good dancer means being like a puppet under the authority of a superior guiding being (like an artist or a god). And being a good puppet is a good way of achieving the "fine" and "straight" posture imperative in a proper education, as discussed, for example, in various dance manuals (Wright 4).

This image of the divine puppet would also be apt, as will be observed below, for Schopenhauer's rather reductive, at times physiological account of the basis of human motivation, i.e., the will present in everything from gravity to the most subtle and complex facets of human behavior. All are objectifications, tendons, and cords of the will. Relatedly, in line with Schopenhauer's view that salvation consists in educating the intellect to renounce the will, the Stranger argues that "each person should always follow one of the cords," namely, "the golden and sacred pull of calculation ... called the common law of the city" (Plato 645a). In at least one important respect, then, Schopenhauer's will amounts to Plato's calculation-law, which equivalence suggests that the laws' design might have considerable bearing on Schopenhauer's thought, specifically their valorization of dance via the chorus.

According to the Stranger, the chorus is the gift of Apollo, Dionysus, and their servantgods the Muses. The Stranger describes the latter as "fellow-dancers" who have "given us the pleasant perception of rhythm and harmony. Using this they move us, and lead us in choruses, joining us together with songs and dances; and that is why they bestowed the name 'choruses'from the 'joy' [charā] which is natural to these activities" (654a). Inspired by this speech, the 
three interlocutors agree that "the first education comes through the Muses," and accept the Stranger's definition of "the educated" person as "the one sufficiently trained in choral performances" (654b). And the chorus is explicitly defined here as "the combination of dance and song taken together as a whole" (654b).

One aspect of this aesthetic education that seems particularly resonant with dancewhether in regard to the rigid lines of ballet or the loose flexibility of hip-hop - is the claim that it is "necessary for the young in the cities to practice fine postures," (656d). Postures are evidently not the exclusive province of dance, however, since the Stranger also claims that "music includes postures" via "rhythm and harmony" (655a). Further, the beauty of a posture is considered evidence of its virtuousness, which calls to mind the centrality of virtue in Schopenhauer's account of salvation via renunciation of the will.

Later in the dialogue, the Stranger claims that "the choral art ... is for us the same as education as a whole," (672e) which reinforces the sense that music-dance and education are coextensive terms. The Stranger then breaks the choral art down into its vocal and non-vocal bodily movement. To the vocal alone belongs melody, he explains, and to the non-vocal belongs posture; but they have rhythm in common. What this means, first, is that music, insofar as it includes postures, which belong to the body exclusively, is itself essentially bodily (rather than just vocal). And second, rhythm is therefore a phenomenon connecting music to dance. Moreover, in light of Schopenhauer's Platonic inheritance, these two points suggest that music should be embodied for Schopenhauer as well. And in what more natural or commonsensical way can music be embodied than through dance (or, more precisely, "re-embodied," insofar as music itself requires embodiment through musicians)? 
One of the Stranger's justifications for this valorization of dance is that "every young thing, so to speak, is incapable of remaining calm in body or in voice, but always seeks to move and cry: young things leap and jump as if they were dancing with pleasure" (Plato 653e). Consequently, hoping for complete stillness is less practical than attempting to introduce productive order and control to the inevitable movement. But according to the Stranger, it is not only children that benefit from intentional movement. Rather, "all bodies benefit from the invigorating stir produced by all sorts of shaking and motions" (789d). For this reason, he asserts that "motion should be as continuous as possible" for nursing-age children (790c). It is also because of this logic that

presumably when mothers want to lull their restless babies to sleep they don't provide stillness but just the opposite, motion; they rock them constantly in their arms, and not with silence but with some melody. It's exactly as if they were charming the children with aulos-playing [a type of flute, often with two pipes], even as is done for the maddened Bacchic revelers, to whom they administer this same cure, which consists of the motion that is dance and music. (790e)

One observes here a second justification of dance, namely that it can function as a form of psychotherapy, a cure for at least one kind of madness. Dance works this way, the Stranger explains, because "the motion brought from without overpowers the fear and the mad motion within, and having overcome it, makes a calm stillness appear in the soul" (791a). Initial motion, at least in the young and the mad, is unavoidable, but the exertion of additional, ordered motion can counterbalance that initial motion into a kind of stillness. In the case of madness, this overpowering "process incites to dancing ... [and] it thereby replaces our mad dispositions with prudent habits" (791b). I will argue below that there is an important linkage between madness and dance in Schopenhauer's thought. 
A third justification for the Stranger's valorization of dance is that dance can be used to buttress the spiritual life of the polis. Dancing activities must be more than just ordered: they must also be sanctioned and sanctified by the polis, and defended against disruptive, creative innovation, although the Stranger describes this censoring position as being "frightening to utter" (797a). "At any rate, this is to be the dogma about it: let no one voice anything or make any dance movement contrary to the public and sacred songs" (800a). Schopenhauer, too, is interested in reducing disorder and conflict as part of the quest to still the will.

Lastly, and counter-intuitively, dance also reduces movement. On the one hand, the Stranger observes, "every human being presumably moves his body more when the pleasures are greater." On the other hand, however, "the human being who is more orderly and who has a better gymnastic training"—including dance training — "in courage moves his body less" (816a). And, in general, reducing movement is helpful in stilling the will for Schopenhauer, so dance could arguably be used to assist in this pursuit.

Despite all of these similarities, it is also important to note one significant dissimilarity between dance in Plato's Laws and in Schopenhauer's philosophy, namely that Plato presents it as a kind of joyful affirmation in the service of the flourishing of the polis, whereas Schopenhauer presents it as a tool in the service of denying the will in order for the drama of existence to cease once and for all. At the same time, however, one could argue that in his more body-denigrating moments, Plato too seems fairly pessimistic and life-denying. Bracketing the latter issue, though, it is precisely in light of the life-affirmation and joy in Plato (and in Advaita thought) that I invoke, in the present essay, the metaphor of the shadow. In essence, it seems to me that Schopenhauer's incorporation of so much from Plato, while nevertheless excising Plato's 
dancing body, illustrates how threatening dance and its affirmations are to the pessimistic conclusions of Schopenhauer's philosophy.

Put differently, dance is like the joyful shadow of a body whose depression is so intense that it attempts to banish its shadow completely (rather than be constantly reminded, perhaps, of that which it is denying/being denied). To return to the figure of Peter Pan from my epigraph, one could argue that the shadow is symbolic of Peter's adulthood, complete with conjugal satisfaction, from which he literally flies away, and that Wendy is the woman (the Beauvoirian shadow of man in the patriarchal imagination) whose intervention Peter desperately needs in order to feel and be complete. To return to Schopenhauer, why does he seek, and appear to need, Plato, if he is truly content with a metaphysics of dance-excluding pessimism? I will return to this important issue in the following section.

\section{Dancing Indian Thought}

Having explored Plato's discourse on dance, I now turn to the work of an inheritor of the bayadere tradition that Schopenhauer references (and that Sparshott alludes to in his footnote on Schopenhauer's affinity for Advaita thought). Avanthi Meduri, a contemporary practitioner and theorist of the classical Indian dance bharatha natyam, argues that the art she practices, the dance of the bayaderes, is inherently related to the Advaita thought that Schopenhauer finds parallel to his own in The World as Will and Representation. Insofar as this is true, I will argue that it should constitute another challenge to Schopenhauer's wholesale rejection of the art of dance as well as a justification for dance's re-inclusion in his philosophy.

According to Meduri, there are two modes of communication in classical Indian theater

(of which bharatha natyam is one aspect): "the lokadharmi mode of explicit or realistic 
representation of emotion" and "the natyadharmi mode of communication, which evokes emotion in an artistic and subtle manner" (Meduri, "Bharatha" 3). The latter is preferred for bharatha natyam, she explains, largely because it reinforces the "illusion of art ... reinforced by the religious themes of dance and drama, stories which are usually extracts from legend and Vedic scriptures" (3). Additionally, this indirect form of communication, according to Meduri, "is expressive of the philosophical values of aucityam (proportion), restraint, and inner quiet" (14). Note that all three of these adjectives, and the last one in particular, call to mind Schopenhauer's rhetoric of quieting the will.

The goal of bharatha natyam as a vehicle of expression of spiritual truth, Meduri writes, is "rasa or aesthetic delight," and is supposed to be available only to the "ideal spectator (sahryada)" (3). And the latter, in theory, "harmonizes differences into unities by the power of his own mind" (3). This ideal spectator is reminiscent of Schopenhauer's "pure subject of willless knowing," which is what a human being becomes, Schopenhauer claims, in the temporary liberation provided by pure aesthetic contemplation. As with Plato's joyful dance in the Laws, however, this emphasis on "delight" clearly differentiates bharatha natyam in a crucial way from Schopenhauerian art-cum-renunciation. Like the ideal spectator, on the other hand, Schopenhauer's pure subject unifies the subject and object of the experience into the aesthetic Idea, whose emergence is the ground, arguably, of a kind of aesthetic delight of its own. That is to say, one could argue that there is a kind of joy, or at least contentment, in detached renunciation (as explored at length, of course, in no less important a text in Vedantic thought than The Bhagavad-Gita).

Meduri then states explicitly what the above passages already imply, that "Indian dance thus encapsulates both in structure and in content the philosophical aspirations of the Indian 
mind" (3). Combining this fact with the contextual nature of the dance, Meduri argues that "to speak about Indian dance, one is entering a philosophical discourse on ethics, aesthetics, and social reality all at once" (3). To substantiate this connection between Indian dance and philosophy, it seems significant that the bayadere practitioner of bharatha natyam was a temple dancer who "danced and sang the stories of God before temple deities to propitiate and entertain them," and "performed the ritual oblations in the temple" (4). The practitioner was also, Meduri writes, "formally married to the temple deity in a sacred thread-ceremony," meaning she was at once both a kind of in-principle virgin to men and a sacred bride of the deity, although in practice she was allowed "discreet sexual relations with priest or king" (4). The practice of the devadasis peaked in the $9^{\text {th }}$ through $12^{\text {th }}$ centuries and continued until the beginning of the $20^{\text {th }}$, at which time, due to complex political disruptions, the temples lost their royal funding and the dancers were forced to abandon their domain. Many began to turn to prostitution just to survive: "expelled from the temple," they "arrived helplessly on the secular stage," leading to what Meduri terms "the special schizophrenia of the contemporary dancer" (7).

Condemning the devadasis as immoral degenerates bringing disgrace to their dancing art, $19^{\text {th }}$ and early-20 2 th century "aestheticians and scholars involved in formulating the history of Indian dance, in attempting to compensate for its progressive 'degradation,' elevated dance to a new high ... to the status of a high religion (vedanta), perceiving it as an experience that embodied transcendental knowledge, cosmic oneness, and religious concentration" (8). Others, including a woman named Balasaraswati, the most famous bharatha natyam dancer in Indian history, were deeply critical of what Balasaraswati termed "this cleaned-up, 'Brahminized' dance" (11). "There is nothing," Balasaraswati once remarked, "in Bharatha Natyam which can be purified afresh; it is divine and is innately so" (11). Whether in denial or in transcendence of 
the physical, bharatha natyam has been repeatedly affirmed as a vehicle of the religious and philosophical truths that Schopenhauer so admires.

Another $20^{\text {th }}$ century strategy to improve the image of bharatha natyam was to encourage public performances, but as Meduri observes, "[t]hat would mean that the dance itself was not any more [innately] respectable than before" (11). Meduri locates the source of this tension in the scholars' imposition of a medieval reinterpretation of bharatha natyam under the guise of a discovery of the truth of the original dance. In other words (and anticipating my discussion below of Schopenhauer and madness), a kind of madness of historical disconnection produced the current tension between the immanent and transcendent aspects of contemporary bharatha natyam dance.

Meduri also identifies another kind of madness related to the devadasis and their art, which she terms "self-mystification" and defines as follows: "confusion that views the new phenomena as continuous and synonymous with the past" (16). This, then, would be a kind of variation on the previously discussed madness of forcing different historical conceptions into one, an inaccurate or unfaithful reconnecting of that which has already been disconnected by a previous madness. Ultimately, calling to mind Schopenhauer's original image of the wheels of the cart crushing the Hindu saint, Meduri writes, "the wheel spins on and dancers spin on it" (19).

In another essay, on improvisation in bharatha natyam, Meduri quotes Balasaraswati's assertion that the dance, in its highest moments, "is the embodiment of music in visual form, a ceremony and an act of devotion. For more than a thousand years, the shastras (rules) have confirmed that an individual dedicated to dance must be equally dedicated to music and must receive training in both the arts" (Meduri, "Multiple Pleasures" 144). Here another thinker, from 
a completely different tradition, aligns perfectly with Plato in presenting dance and music as essentially interwoven, thereby making Schopenhauer's separation of the two arts seem even more problematic. Coming closer to Schopenhauer's privileging of music, however, Balasaraswati relegates her dance to a dependent position relative to music: "The dancer's mimetic expression and her hand gestures, in other words, fold into the cadences of the melody and rhythm and lose their singularity and distinctiveness" (144). In describing the interrelationship between the bharatha natyam dancer and the poetic text upon which she improvises, Meduri asks: "Is the dancer's body supplementing the text, or is the singer's rendition of the text line supplementing the dancing body? Where, in fact, is the dancing body? Is the body residing in the textual composition or in the gestural language of the dance?" (146) These questions, in turn, recall Schopenhauer's usage of the metaphor of dance to describe the human condition. Is the dancing body simply that of the individual dancer, or could one think of the entire world of representation, or at least the world of music, as the dancing body of the will?

Along these lines, I turn once more to Balasaraswati as she observes that "the spiritual quality of Bharatanatyam is achieved not through the elimination of the sensual but through the seemingly sensual itself, thereby sublimating it" (149). The dance, to put it in Schopenhauer's terms, is the use of the body (facilitated by music) to perform the inherent spirituality of the body, the freeing of the body as objectification of the will from the body as the representation of the will. Note, however, in regard to the aforementioned issue of joyful life-affirmation, that "sublimate" is a problematic verb that begs the question as to how much, or in what ways, carnality is affirmed as such. Either way, though, Balasaraswati's approach seems a perfectly legitimate route to Schopenhauerian salvation. The question thus repeats more insistently: why 
does Schopenhauer both neglect and condemn dance? Is this perhaps a symptom of what he himself would regard as a kind of pure madness?

\section{Reattaching the Shadow}

I will attempt in this section to move from an analysis of dance's fleeting explicit appearances in Schopenhauer's work, to dance's relationship to Schopenhauer's philosophy as a whole. Ironically, the latter amounts to Schopenhauer's own failure to "re-member" dance, in the etymological sense of choreographically re-placing the limbs (or "members") of the body. In other words, Schopenhauer's irrational excision of dance from his account of the world performs Schopenhauer's own conception of madness - namely, a failure to see the whole due to an obsession with one or more parts which excludes one or more other parts. In this case, the pessimism-inducing aspect of the world is Schopenhauer's obsessive focus, and dance, along with all of its embodied joy, is what gets excluded.

Schopenhauer defines madness as the dysfunction of the memory, resulting from "gaps in [mad peoples'] recollection that they fill up with fictions" (Schopenhauer, WWR 192). In other words, the world in actuality is composed of an unbroken chain of events, and thus a healthy memory codes it as such, matching memory to event in a one-to-one ratio. "Mad" people, by contrast, although they implicitly recognize the need to reconstitute this chain of events in memory, are forced to resort to delusional fictions in order to do so.

Like others in the Romantic era, Schopenhauer considers such "madness" as closely related to genius, noting that the extraordinarily gifted "exhibit several weaknesses that actually are closely akin to madness" (190). More specifically, the "point of contact with the genius" is

that the mad person "fails to recognize the connexion, the relations, and therefore goes astray and 
talks nonsense" (193). The difference between madness and genius, Schopenhauer seems to imply here, regards that which is used to fill in the gaps. "Mad" people fill in gaps with idiosyncratic fictions that serve no purpose beyond causing dysfunction and/or distress, while geniuses fill them with socially relevant creations, or at least somewhat functional fictions.

Based on my previous considerations of Plato and classical Indian dance, this definition of madness from Schopenhauer would, ironically, also seem to describe his own failure to see the connection between music and dance, their intricately interwoven relationship. That is to say, for most of human history, Western and non-Western alike, music and dance have appeared together in holistic performances and practices, up until (perhaps) the creation of absolute music in the $19^{\text {th }}$ century and the modernist revolution in concert dance beginning in the $20^{\text {th }}$ century. ${ }^{6}$ The genius, Schopenhauer writes, "sees extremes," although he "knows the Ideas perfectly, but not the individuals" (194). Perhaps this, too, is literally true of its author: Schopenhauer knows the Ideas qua music, but cannot recognize the same Ideas qua objectified by individual dancers' moving to music. Moreover, at a more basic level, Schopenhauer divorces music from its own basic embodiments, since musical performances require bodies to bring them to life (whether in the form of live musicians or, today, those who program digital music).

Music and dance seem even more relevant to Schopenhauer's discussion of madness in light of his view that actors are, of all professionals, those most prone to madness. This is so, he writes, because "every evening the actor strives to forget himself entirely, in order to be quite a different person" (400). The connection to music and dance here, of course, is that actors often have to sing and dance in their roles. In addition to this necessary self-forgetfulness that dancers "inherit" as actors, dancers are also subjected to self-effacement vis-à-vis the whims of their choreographers. All of this raises with a new urgency the question as to whether Schopenhauer is 
himself "mad," in addition perhaps to the dancers whose art he attacks here. If so, might there nevertheless be a cure for Schopenhauer's madness in his own thought? In the terms of my essay's opening quote, could I perhaps play Wendy to Schopenhauer's Peter Pan, and sew this Platonic/Vedantic shadow back onto the frail body of his position on dance-using the thread of his own thought?

One reason why I chose this metaphor of bodily shadows is that the issue of embodiment is absolutely crucial for Schopenhauer. Every knower in the world, he claims, is "rooted in that world," and all knowledge is "given entirely through the medium of a body" (99). The body, Schopenhauer acknowledges, is our indispensable mode of access to the world, though it harnesses within itself two separate modalities, and is therefore "given in two entirely different ways." The first way, he explains, is "in intelligent perception as representation, as an object among objects, liable to the laws of these objects." An example here would be the body of the dancer on stage that one watches from the audience. In the second way, though, "as what is known immediately," the body is "denoted by the word will. Every true act of his will is at once and inevitably a movement of his body" (100). This is the same body that is watched from the audience, but this time as experienced by the dancer.

Schopenhauer even goes so far as to assert that the "act of will and the action of the body ... are one and the same thing," a claim which applies "also to involuntary movement following on mere stimuli; indeed the whole body is nothing but the objectified will, i.e., will that has become representation" (100). Thus, when the dancer dances, the will dances. Put slightly differently, "the will is knowledge a priori of the body," and "the body is knowledge a posteriori of the will" (100). The will dances the body, and the body reveals the will in its dance. Body and will for Schopenhauer are thus two sides of the same coin or, more precisely, the same coin spun 
clockwise or counterclockwise, so inseparable that Schopenhauer asserts that "I cannot really imagine this will without my body" (102). Note also that this claim is literally true in terms of contemporary science, since without the body and its brain, imagination per se is impossible. Consequently, science tells us that without the ability to dance (at least in theory), there is no will.

Shifting to a finer-grained analysis, and one even more resonant with dance, Schopenhauer writes that "the whole body must be nothing but my will become visible" (107). This fact extends, for him, even to the specificity of body parts, which, he writes, "must correspond completely to the chief demands and desires by which the will manifests itself ... Teeth, gullet, and intestinal canal are objectified hunger; the genitals are objectified sexual impulse; grasping hands and nimble feet correspond to the more indirect strivings of the will which they represent" (108). "Nimble feet" is a phrase most commonly associated in the history of philosophy with Nietzsche, who extended Schopenhauer's work in his own famous valorization of dance (most explicitly in The Birth of Tragedy). Already at the level of semantics, additionally, the word "nimble" seems to cry out to be attached to a word for dancing. Following out the logic of the passage, if teeth are objectified hunger, and genitals are objectified libido, the closest analogue to skillfully moving feet would seem to be dancing, with feet as objectifications of "the more indirect strivings" of dance.

Dance is again suggested by Schopenhauer's discussion of the human body as subject of sculpture and painting. Here he returns to his previous analysis of will as objectified through specific body parts, but this time putting them more explicitly in motion. What results from this more dynamic account is his conception of grace, which is as follows: "the adequate manifestation of the will through its temporal phenomenon, in other words, the perfectly correct 
expression of each act of will through the movement which objectifies it" (224). In short, grace is the body's perfect adequacy to the will, as perhaps when a dancer wills her/his body to do the splits, to which the body smoothly acquiesces. And when grace is united with beauty (with the latter for Schopenhauer being the object of art), he defines their fusion as "the most distinct phenomenon of the will at its highest grade of its objectification" (224). Grace, especially when explicitly linked to art, is clearly a concept with a privileged connection to dance, and thus Schopenhauer's discussion of embodiment leads yet again to dance.

More importantly for my concerns, though, Schopenhauer's discussion of embodiment is also intimately linked to his discussion of music, the analysis of which is rife with bodily metaphors. In one of many examples, he compares musical harmonics to the fact that "bodies" of nature "come into existence through gradual development out of the mass of the planet" (258). In other words, material bodies are made up of material arranged in complex and exacting ratios and relationships. In a second example, he compares the "inexhaustibleness of possible melodies" to "the inexhaustibleness of nature in the difference of individuals, physiognomies, and courses of life" (261). That is, just as a melody is an ordered succession of common particles with varied qualities, so an organism is an ordered succession of matter with its own distinctive qualities (as in an animal and its DNA). In a third example, he compares the composer to a "magnetic somnambulist," a patient in a state of suggestibility due to hypnosis, who "gives information about things of which she has no conception when awake" (260). One imagines here the composer (such as Nietzsche's and Wagner's favorite example, Beethoven) writing music under the spell of divine inspiration, taking down what the Muses dictate.

In a parallel fashion, the dancer can be thought of as (a) the aesthetically-pleasing harmony of a human being's movements; (b) the unique melody of his or her physiognomy in its 
life-course; and (c) the hypnotized patient subject to the will of the music or the choreographer, able to perform actions that s/he cannot necessarily put into words. To unpack these comparisons, first, dance puts the parts of the dancer, which share a common flesh, into various well-proportioned relationships that produce an aesthetically satisfying (or otherwise strategically-chosen) reaction in the audience. Second, the dancer's progress through a piece of choreography repeats, in a condensed or concentrated way, the melodic line of a given human being's path through life. And third, the dancer who most fully embraces the choreographer's work is able to bring it most fully to life in performance, even though that dancer might be unable to verbally articulate the embracing or performance.

Also resonant with dance is Schopenhauer's likening of music to "geometrical figures and numbers, which are the universal forms of all possible objects of experience and are a priori applicable to them all, and yet are not abstract, but perceptible and thoroughly definite" (262). That is, dancers too are (among many other things) definite, perceptible geometrical figures (262). The likeness is thus apt for dance as well as for music.

Moving on to Vol. II's chapter on music, Schopenhauer compares the suffering that for him is life itself to a kind of music in which "we are ourselves the vibrating string that is stretched and plucked," (451) a formulation which could easily be offered as a phenomenological description of dance experience. He also compares rhythm in music to symmetry in architecture (a discipline whose kinship to dance has already been observed), referencing Goethe's famous quote that "architecture is frozen music" (453-4). Interpolating my previous consideration of architecture as metaphorically frozen dance, the result of this substitution would be that "frozen dance is frozen music." By implication, then, non-frozen (that is, living) music would thus be non-frozen (or living) dance. Or, more simply, music would be dance. And the truth of this 
statement is manifest, among other ways, in how various famous musicians, such as Louis Armstrong (or any other singer in a tradition, such as jazz, in which certain musical and dance forms are intimately intertwined), move their bodies during their own musical performances-in what one would be hard-pressed not to admit is a kind of dance (see Hall, "Syncopated Communities").

Music, alone of the arts for Schopenhauer, but in common with the body, is an immediate objectification of the will, and the world, he writes, is "embodied music" (Schopenhauer, WWR 263). Thus, instantiating from the universal to the particular, the body as part of the world must also be embodied music, including (and perhaps especially) when it is involved in the activity of dance. And if dance is embodied music, and music is embodied will, then by categorical syllogism, dance is embodied will. And this means, finally, that Schopenhauer's thought leads directly to the same position advocated above by Sparshott: that dance can serve as his ultimate art. Contra Sparshott, however, as I have attempted to show, this requires a significant torsion in Schopenhauer toward the joy and affirmation that dance (including Shiva's destroying-creating dance) entails.

In closing, and to return to the language of my opening quote, when these two discourses are thus sewn together, it becomes clear — at the seams, where the shadow meets the body - that dance, as the art closest to our two closest connections to the will — the body and music — should be for Schopenhauer not only duly acknowledged and even valorized, but the ultimate art of the objectification of the will, and even a potentially viable route to the salvation of the world- $-\mathrm{a}$ Nietzschean salvation of joyful affirmation. 


\section{Notes}

${ }^{1}$ Also notable is the memorable phrase in "On Religion" that all humans "dance into the arms of death" (Schopenhauer, Essays 180). On a more hopeful note, however, "Councils and Maxims" compares the lonely superior human being to a good dancer at a ball filled with "lame" people (Parerga 58).

2 About the closest this literature comes to dance is found in Barbara Hannan's 2009 monograph, which includes a description of her own firsthand experience, one sleepless night, of the "slow dance of the earth around the sun," as an example of Schopenhauer's claim that there is peace to be found in realizing our own insignificance (Hannan 106).

${ }^{3}$ See, for example, Carroll; the 2005 special issue of Topoi dedicated to dance; Postl; Hall; and the exemplary work of Foster.

4 I have contributed to this discussion in three recent articles: see Hall, "Syncopated Communities," "Revalorized Black Embodiment" and "Choreographing the Borderline."

5 Architecture's purpose, writes Schopenhauer, is to express the lowest-grade Ideas, those of "gravity, cohesion, rigidity, hardness ... and along with these, light" (WWR 214). Its "material" is the "conflict between gravity and rigidity" - two important forces in dance as well - and its "problem" it to deprive "these indestructible forces of the shortest path to their satisfaction, and keeping them in suspense through a circuitous path" (214) — which could easily be read as a poetic phenomenological account of dance.

${ }^{6}$ For more on absolute music, see Burnham 890.

\section{Works Cited}

Hall, Joshua Maloy. "Choreographing the Borderline: Dancing with Kristeva." Philosophy Today 56, no. 1 (2012): 49-58.

—. "Revalorized Black Embodiment: Dancing with Fanon." Journal of Black Studies 43, no. 3 (2012): 274-288.

—. "Syncopated Communities: Dancing with Ellison." Southern Literary Journal 45, no. 2 (2013): 57-71. 
Burnham, Scott. "Form." The Cambridge History of Western Music Theory. Ed. T. Christensen. Cambridge: Cambridge University Press, 2002.

Carroll, Noël. Art in Three Dimensions. Oxford: Oxford University Press, 2012.

Foster, Susan Leigh. Choreographing Empathy: Kinesthesia in Performance. New York: Routledge, 2010.

Hannan, Barbara. The Riddle of the World: A Reconsideration of Schopenhauer's Philosophy. Oxford: Oxford University Press, 2009.

Meduri, Avanthi. "Bharatha Natyam—What are You?" Asian Theatre Journal 5, no. 1 (1988): 1 22 .

- "Multiple Pleasures: Improvisation in Bharatanatyam." Taken by Surprise: A Dance Improvisation Reader. Ed. A. Albright and D. Gere. Middletown: Wesleyan, 2003: 141-150.

Nietzsche, Friedrich. The Birth of Tragedy and the Case of Wagner. Trans. W. Kaufmann. New York: Vintage, 1967.

Postl, Gertrud. "From Gender as Performative to Feminist Performance Art: Judith Butler and Valie Export.” Radical Philosophy Review 12, no. 1-2 (2009): 87-103.

Plato. The Laws of Plato. Trans. T. Pangle, Chicago: University of Chicago Press, 1988.

Schopenhauer, Arthur. Essays and Aphorisms. Trans. R. J. Hollingdale. New York: Penguin, 1973.

-. Parerga and Paralipomena: A Collection of Philosophical Essays. Trans. T. Bailey Saunders. New York: Cosimo, 2007.

-. The World as Will and Representation: Vols. 1 \& 2. Trans. E. F. J. Payne. New York: Dover, 1966.

Sparshott, Francis. "On the Question: 'Why Do Philosophers Neglect the Aesthetics of the Dance?" Dance Research Journal 15, no. 1 (1982): 5-30. 
Topoi 24, no. 2 (2005), issue on dance and philosophy.

Wright, Judy Patterson. Social Dance: Steps to Success. New York: Leisure, 1992. 